DOI: $10.31168 / 0459-6.04$

Л. Б. Карпенко (Самара, Россия)

\title{
Возрождение отечественной славистики: к 110-летию профессора С. Б. Бернштейна
}

В истории науки есть знаковые фикуры, определяющие направления, проблематику, выработку исследовательских подходов. Безусловно, для отечественной славистики такой личностью в середине ХХ в. явился профрессор Самуил Борисович Бернштейн, который стал научным организатором возрождения всей славистической отрасли. Советскому славяноведению чрезвычайно повезло, когда, не имея шансов в связи с пролетарской политикой поступить на философрское отделение МГУ, Самуил Бернштейн пришел в славистику. В своих мемуарах «Зигзаги памяти» Бернштейн вспоминает 20-е годы, когда он прибыл в Москву из далекого НикольскУссурийска завоевывать фрилософрское отделение Первого Московского университета. Тогда по политическим мотивам двери высших учебных заведений для детей из среды интеллигенции фрактически были закрыты. Несмотря на блестяще сданные вступительные экзамены, Бернштейн не был зачислен на желанный фрилософрский профриль, а поступил на этнографическое отделение, на котором и получил основательную подготовку по славяноведению. Уже спустя 15 лет после поступления в МГУ, в августе 1943 г., он был назначен заместителем заведующего кафедрой славянской филологии, которой посвятил себя целиком, «отдал все свои силы, все свои интеллектуальные возможности». Вызывает удивление невероятная энергия, целеустремленность, работоспособность ученого. Страницы дневника осени-зимы военного 1943 г. раскрывают масштаб деятельности С. Б. Бернштейна: он одновременно занимается организацией славянского отделения МГУ (необходимость создания которого 
руководством страны была осознана уже в первые годы войны), подготовкой кадров, чтением лекционных курсов и докладов, организацией аспирантуры, изучением славянских диалектов, редактированием и изданием русско-болгарского словаря, составлением библиографии по болгарской диалектологии, написанием серии статей для Большой советской энциклопедии по славянским языкам и литературам, начинает работу над сравнительной грамматикой славянских языков и над грамматическим очерком болгарского языка... С не меньшей интенсивностью С. Б. Бернштейн работает и в последующие годы, связанные с защитой докторской диссертации, организацией сектора в Институте славяноведения и балканистики. Значительным вкладом в разработку славянской исторической диалектологии, начатой трудами академиков А.И. Соболевского и А.А.Шахматова, стало докторское диссертационное исследование С. Б. Бернштейна на тему «Язык валашских грамот XIV-XV ст.», защищенное в Институте языкознания АН CCCP в 1946 г. В 1958 г. последовало издание «Атласа болгарских говоров». В 1951 г. С. Б. Бернштейн возглавил сектор славянского языкознания, который был к этому моменту выделен в Институте славяноведения и балканистики.

Без преувеличения можно сказать, что работа по возрождению отечественной славистики была развернута во всех направлениях. В научном наследии ученого есть и ряд исследований по кирилло-медодиевской проблематике, в частности опубликованная в 1984 г. монография «Константин-Философр и Мефродий», содержащая основательный анализ агиографических источников о жизни и деятельности создателей славянской письменности. С. Б. Бернштейн не только сформировал структурные отделения славистики МГУ и Института славяноведения, но заложил основы системного и точного подхода в научных исследованиях. Обдумывая концепцию сравнительной грамматики славянских языков, он писал: 
«Должна быть тщательно обработана праславянская часть и история отдельных общеславянских явлений в основных славянских языках» (Бернштейн 2002: 31), стремился реализовать комплексный диахронный подход. Такое видение будущего труда по компаративистике возникло у него после чтения доклада Н. Н. Дурново и ряда работ Р. О.Якобсона, творчески соединивших синхронию и диахронию. Когда в 1961 г. вышел из печати первый том «Очерка сравнительной грамматики славянских языков», ученики С.Б. Бернштейна увидели в нем отражение лекций, которые читались ученым на фрилологическом фракультете МГУ. И изданные тома сравнительной грамматики, и стоящие за ними лекционные университетские курсы служат свидетельством высочайшего класса научной и преподавательской деятельности С. Б. Бернштейна. Соратники ученого не раз отмечали, что жизненный путь С. Б. Бернштейна - это пример преданного служения призванию и делу, найденному еще в молодые годы. Необходимо упомянуть и такую важную черту ученого, как открытость идеям, новым гипотезам и концепциям. Трудами учеников С.Б. Бернштейна, воспитанных им подвижников продолжается развитие отечественной славистики и сегодня.

\section{Литература}

Бернштейн 2002 - Бернштейн С. Б. Зигзаги памяти. Воспоминания. Дневниковые записи / отв. ред. В. Н. Топоров. М.: [Ин-т славяноведения РАН], 2002.

\section{The revival of Russian Slavic Studies: to the $110^{\text {th }}$ Anniversary of Professor S. Bernstein}

The report traces the role of the outstanding Soviet slavist, professor S. Bernstein in the revival of Russian Slavic studies in the second half of the XX century. The author relies on the memoirs of 
scientists of the Institute of Slavic Studies and Moscow University and on the materials of the book of memoirs of S. Bernstein "Zigzags of Memory" (2002). The name "Zigzags of memory" correlates not only with the memories of the scientist, but also with the zigzags of the history of Russian Slavic science. The author traces the path of Slavic science in the Soviet period, which was thorny due to the well-known persecution of slavistics in the 20-30 years of the XX century. In the middle of the XX century, prof. S. B. Bernstein became the organizer of the revival of the entire Slavic branch. The role of the scientist in the organization of the Slavic department of Moscow State University and the training of slavists, in the work of the Institute of Slavic Studies, in the development of a number of significant science areas is shown: slavic dialectology and linguogeography, comparative historical grammar of slavic languages, ethnolinguistics and slavic antiquities, Cyril and Methodius problems, etc.

DOI: $10.31168 / 0459-6.05$

\section{М. А. Штудинер (Москва, Россия) \\ Типологическая классификация фонетических систем славянских языков}

Самуил Борисович Бернштейн строго разграничивал праславянские и общеславянские процессы. Праславянские - это фонетические процессы, происходившие в праславянском языке, а общеславянские - это процессы, имевшие место в славянских языках уже в период их раздельного существования, но обусловленные, вызванные к жизни родством, общностью происхождения этих языков (Бернштейн 1961: 43).

Типологические особенности фонетических систем славянских языков рассматриваются в докладе сквозь призму одного из общеславянских явлений — рефлексацию долгих 